\title{
Family Trees Representing the Finitely Proliferative Nature of Cultured Rat Liver Cells
}

\author{
Toshiharu Matsumura*, Kiyofumi Masuda ${ }^{1}$, Yoshinori Murakami ${ }^{2}$ and \\ Ryuji Konishi
}

Department of Pathobiochemical Cell Research, Institute of Medical Science, University of Tokyo, Shirokanedai, Minato-ku, Tokyo 108, Japan

\begin{abstract}
Family trees of rat liver epithelial-like cells in primary culture were obtained by cinemicrographic analysis. With few exceptions the proliferative profiles reconstituted from these family trees showed limited proliferation. This limitation was not due to post-confluence inhibition of proliferation or to nutritional deprivation during time lapse cinemicrography, but to the finite potential of clonal proliferation. In these family trees a cell entered mitosis, incomplete division, death, or a long interphase with no detectable termination. These family trees successfully related the life phases of the individual cells that compose the population to the limited nature of proliferative potential as observed in clonal cell populations.
\end{abstract}

A population of normal diploid mammalian somatic cells proliferates in culture for a limited number of serial passages $(10,11)$; whereas cell populations that proliferate indefinitely come from malignant tissue, or are produced from normal cells spontaneously $(15,26)$. To relate the proliferative life span of a cell population to the life phases of component cells, one may use genealogy as a direct approach. In fact, family trees of human diploid fibroblasts (HDFs) that cover several different segments of their proliferative life span have given us a direct view of variations in intermitotic periods and parent-daughter relationships among the cells (1-3).

Indefinitely proliferative populations also have been characterized genealogically $(21,22,25,28)$. These previous studies have only partly succeeded in showing the the difference between finite life and indefinite life: A difference between these two types of life, although suggested (9), has not been established on the basis of genealogical data (24).

We here describe a culture system of rat liver epithelial-like cells (RLEC) which we found suitable for family tree analyses. The cultivation of cells of this type has a long history $(5,7,8,12,13,23,27)$. Biochemical studies have indicated that RLECs are a premature stage of hepatic stem cells or bile duct cells $(8,12)$. Most previous

* To whom all correspondence should be addressed.

Abbreviations used: HDF, human diploid fibroblasts; RLEC, rat liver epithelial-like cells.

${ }^{1}$ On leave from the Department of Hygienic Chemistry Meiji College of Pharmacology, Tanashi, Tokyo, Japan.

${ }^{2}$ On leave from the Faculty of Medicine, University of Tokyo, Hongo, Bunkyo-ku, Tokyo 112 , Japan. 
reports on cultured cells of this type were concerned with established (indefinitely proliferative) cell lines $(5,7,8,12,23,27)$. These lines often have kept diploidy for a long time during proliferation $(23,27)$.

As reported here, however, the majority of RLEC clones in the early culture stage show limited proliferative potential. We will show family trees which relate this limited proliferative potential of a cell population to the life phases of the individual cells that compose the population.

\section{MATERIALS AND METHODS}

Cell culture. Eagle's minimum essential medium supplemented with $10 \% \mathrm{v} / \mathrm{v}$ heatinactivated fetal bovine serum (FBS) and $60 \mu \mathrm{g} / \mathrm{ml}$ kanamycin is referred to as MEM·FBS. Katsuta's DM-160 (14) (Kyokuto Pharmaceutical Industries Co., Tokyo) supplemented with $10 \% \mathrm{v} / \mathrm{v}$ FBS, $60 \mu \mathrm{g} / \mathrm{ml}$ kanamycin, $0.4 \mu \mathrm{g} / \mathrm{ml}$ cortisole acetate, $1.6 \times 10^{-1}$ units $/ \mathrm{ml}$ insulin, and glucose with the final concentration brought to $5 \mathrm{mg} / \mathrm{ml}$, was the growth medium used.

Livers were removed aseptically from fetal (ca. 19 to 20 days of gestation) JAR-2 or Sprague Dawley rats of unknown sex, then combined and finely fragmented. Until use, the fragments were preserved at $-196^{\circ} \mathrm{C}$ in sealed glass ampules containing MEM.FBS supplemented with $10 \% \mathrm{v} / \mathrm{v}$ dimethyl sulfoxide under the freezing schedule described previously (30).

For primary cell culture, frozen tissue fragments were thawed and freed from the cryoprotecting solution then dissociated by dispase (Godo Shusei Co., Tokyo) treatment as described elsewhere (18). Briefly, tissue fragments were incubated in MEM.FBS supplemented with $100 \mathrm{U} / \mathrm{ml}$ dispase for 30 or $60 \mathrm{~min}$ under constant agitation. The dissociated cells were freed from protease by centrifugation. The centrifuged cells then were suspended in growth medium, and diluted in a two fold sequence, after which they were inoculated in $6-\mathrm{cm}$ plastic plates containing $4 \mathrm{ml}$ of growth medium or in T25 plastic containers containing $8 \mathrm{ml}$. To avoid fibroblast growth, the initiation of a primary culture with a low inoculum density was important. The primary culture containers were incubated in a humidified atmosphere containing $5 \% \mathrm{CO}_{2}$ in air and were fed once or twice a week, depending on the density of cells. To count the number of cells in a colony, we marked the colony on the back of its culture dish, then photographed it twice a week.

Cells were exposed to tritiated thymidine $\left({ }^{3} \mathrm{H}-\mathrm{TdR}\right)$, after which they were autoradiographed by a modification of a previously described method (6). Briefly, $24 \mathrm{~h}$ before exposure plates containing colony-forming cells were supplied fresh growth medium. The medium then was supplemented with $0.05 \mu \mathrm{Ci} / \mathrm{ml}{ }^{3} \mathrm{H}-\mathrm{TdR}$ (methyl- ${ }^{3} \mathrm{H}-\mathrm{TdR}, 47 \mu \mathrm{Ci} / \mathrm{mmole}$, Amersham Int. Ltd, Amersham, U.K.) and incubated for another $24 \mathrm{~h}$. The plastes were fixed, then covered with autoradiographic emulsion (NR-M2, Konishiroku, Photo. Industries, Tokyo), after which they were exposed for 8 days in darkness, developed. After developing the plates, we examined them by microscopy to check the distribution of labelled cells.

Family trees. A colony in a sealed T25 flask was cinemicrographed with a phase-contrast inverted microscope. Magnification was $\times 50$, exposure time $1 \mathrm{sec}$, and the interval between exposures 4 or $8 \mathrm{~min}$. Mitosis was detected by the sequence of cytoplasmic contraction, cytokinesis and the subsequent spreading out of the cytoplasm that resulted in two daughter cells. Incomplete mitosis was a mitosis followed immediately by the fusion of the two daughter cells. 
For some cells an event, which we refer to as cytoplasmic contraction, took place, in which only cytoplasmic contraction and the subsequent spreading of the cytoplasm could be clearly detected; cytokinesis was not visually detected. Both incomplete mitosis and cytoplasmic contraction are called incomplete divisions in this paper.

Cell death was the sudden termination of cell movement followed by the shrivelling up of the cytoplasm. For some cells no terminating events were detected, either because they moved out of sight or they survived the cinemicrography.

A proliferative profile was reconstituted from each family tree. This profile was corrected for cells that had moved out of cinemicrographic sight. In this correction we assumed that an escaping cell, after moving away, would proliferate at the average rate of proliferation of the cells remaining in the family tree.

\section{RESULTS}

More than 15 primary cultures were put through time-lapse cinemicrography. Because they showed similar time courses for declining proliferation, detailed analysis were made for three cultures; i.e. RLEC-1, RLEC-2 and RLEC-3 in Table 1. Although the proliferation of all the clones in these cultures ceased, the number of cells that they produced varied. Three family frees $(A, B$ and $C$ in Table 1) came from clones that produced relatively large cell number. In all three, the frequency of dividing cells decreased and the frequency of interphase cells increased with time.

A proliferative profile for each family tree was reconstituted. In all three profiles, clones proliferated rapidly in the beginning, then the rate of proliferation decreased, after which there was a phase with little increase or decrease in the number of clonal cells. In this last phase, the cell population maintained a balance between dividing cells and dying cells. Fig. 1 (RLEC-2) illustrates this situation.

The observed decline in clonal proliferation might have been due to the limited proliferative potential of the clones, to post-confluence inhibition of proliferation, to nutritional deprivation during time lapse cinemicrography or all three. Also, as some cells moved out of the sight during cinemicrography, there was the possibility that the moving cells might differ in proliferative potential from cells remaining in sight. To To assess these possibilities we devised several experiments:

We obtained proliferative profiles of individual colonies by counting the total

TABLE 1. ChARACTERISTICS OF FAMILY TREES

\begin{tabular}{ccccccrc}
$\begin{array}{c}\text { Cell culture } \\
\text { ID. name }\end{array}$ & $\left.\begin{array}{c}\text { Cinemicrography } \\
\text { day of } \\
\text { primary culture }\end{array}\right)$ & $\begin{array}{c}\text { Limited } \\
\text { proliferation }\end{array}$ & $\begin{array}{c}\text { Family tree } \\
\text { I.D. name }\end{array}$ & $\mathrm{N}_{\mathrm{t}^{\mathrm{a}}}$ & $\mathrm{N}_{\mathrm{o}} \mathrm{b}^{\mathrm{b}}$ & $\mathrm{N}_{\mathrm{r}}{ }^{\mathrm{c}}$ \\
\hline RLEC-1 & 5th to 18th & Yes & $A$ & 63 & 16 & 11 \\
RLEC-2 & 4th to 26th & Yes & $B^{\mathrm{d}}$ & 39 & 7 & 7 \\
RLEC-3 & 3rd to 14th & Yes & $C^{\text {d }}$ & 117 & 19 & 16 \\
\hline
\end{tabular}

a $\mathrm{N}_{\mathrm{t}}$ : Total number of interphase cells in a family tree.

b $\mathrm{N}_{\mathrm{o}}$ : Number of cells moving out of sight, and thus lost from the family tree.

c $\mathrm{N}_{\mathrm{r}}$ : Number of cells remaining in the family three at the termination of cinemicrography.

d These two family trees were obtained from two clones in a single colony.

e This culture was obtained from the same tissue batch as RLEC-2.

f Family Tree $D$ is an assembly of four family trees with small proliferation potentials (See Fig. 3). 

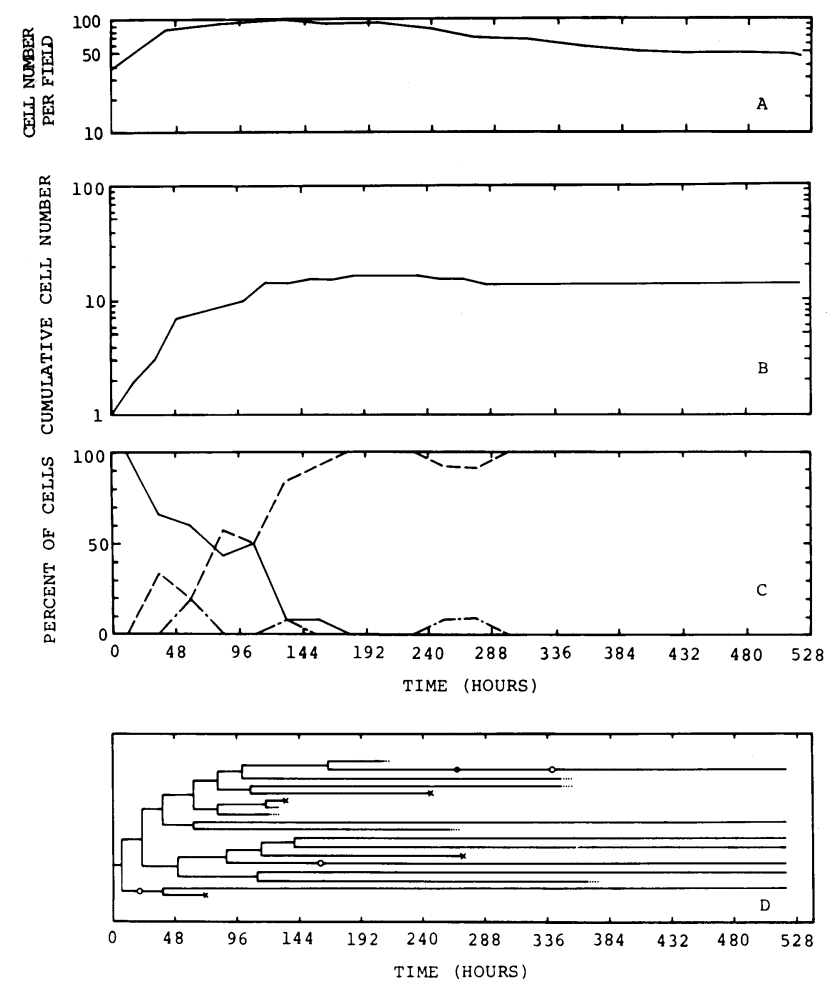

Fig. 1. Changes in characteristics of proliferation and a family tree determined cinemicrographically during the development of an RLEC clone in RLEC-2 primary culture. A: Number of cells present in the cinemicrographic field $\left(=0.50 \mathrm{~mm}^{2}\right)$ as an indication of cell density. B: Proliferative profile reconstituted from Family Tree $B$. This profile has been corrected for cells moving out of the cinemicrographic field as described in Materials And Methods. C: Percentage of dividing cells $(-)$, surviving cells (-- ) and dying cells $(--\infty)$ in Family Tree $B$. The percentage was obtained for cells in each $24-\mathrm{h}$ segment of the family tree. D: Family Tree $B$ (Ref. to Table 1). Events on a family tree are mitosis $(-\square)$, incomplete division (-O-), cytoplasmic contraction (- - ), cell death $(-x)$, and moving out of sight (- - - ).

number of cells in each. Because a colony grew large in primary culture, we also counted the number of cells in secondary culture colonies. In all of the five primary-culture colonies examined, cell proliferation slowed down. In each of the six secondaryculture colonies examined, proliferation ceased (Fig. 2). This result shows that the declining proliferation described earlier for the reconstituted profile qualitatively represents that of an average clone of cultured RLEC.

The maximum number of cells varied greatly among colonies in a single culture dish (Fig. 2). The maximum number also varied among clones in a single colony (See Family Tree $D$ which shows cells with small proliferative potentials [Fig. 3]). These results, together with the fact that the growth medium was renewed periodically during cultivation, indicate that nutritional deprivation as a major factor in the decline in proliferation can be considered negligible.

In the primary culture colonies the number of cells in the cinemicrographic field first increased then decreased. Cells were separated by spaces when proliferation 


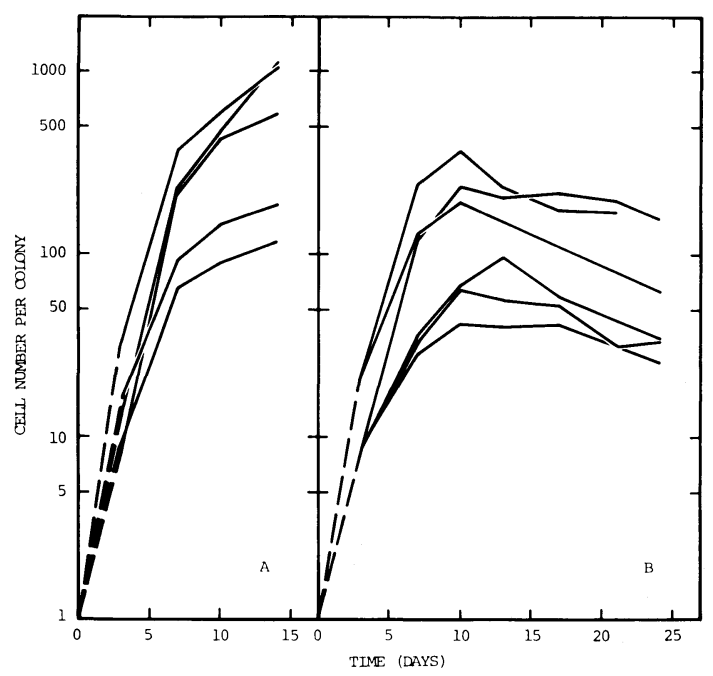

Fig. 2. A: Proliferative profiles for five colonies in one primary culture dish. Time 0 in this figure is $24 \mathrm{~h}$ after the beginning of primary culture. B: Proliferative profiles for six colonies in one secondary culture dish. The secondary culture was obtained by trypsinization from a replicate primary culture dish on the eighth day. A half of one secondary-culture colony was removed on the 21 st day by a glass needle with a round top. The number of cells in the remaining half colony did not increase thereafter.

declined. Column A of Fig. 1 and Fig. 4 show this phenomenon for RLEC-2. In the colonial proliferation experiment shown in Fig. 2, half of a fully grown colony was removed mechanically. No cell proliferation was detected in the cells in the remaining half colony. Apparently, in a declining colony, cells in its center, as well as along its periphery, had already lost their proliferative ability. These results show that the decrease in proliferation was not due to post-confluence inhibition of proliferation.

To examine whether S-phase cells in particular were localized along the periphery of a colony, we exposed colonies that were nearing full development to ${ }^{3} \mathrm{H}-\mathrm{TdR}$ for

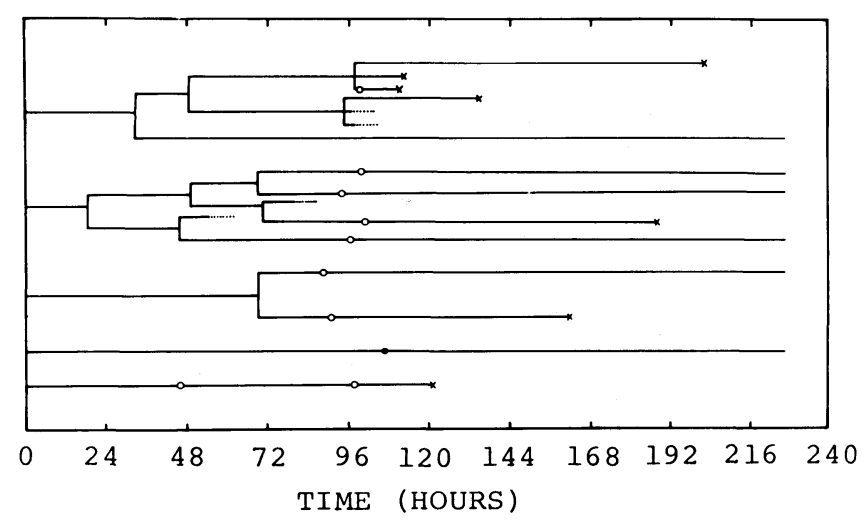

Fig. 3. Five small family trees from RLEC-3 primary culture. The family tree at the top of this figure shows multipolar division. With the exception of this rare case, the remaining family trees collectively have been named Family Tree $D$ (see Table 1 ). 

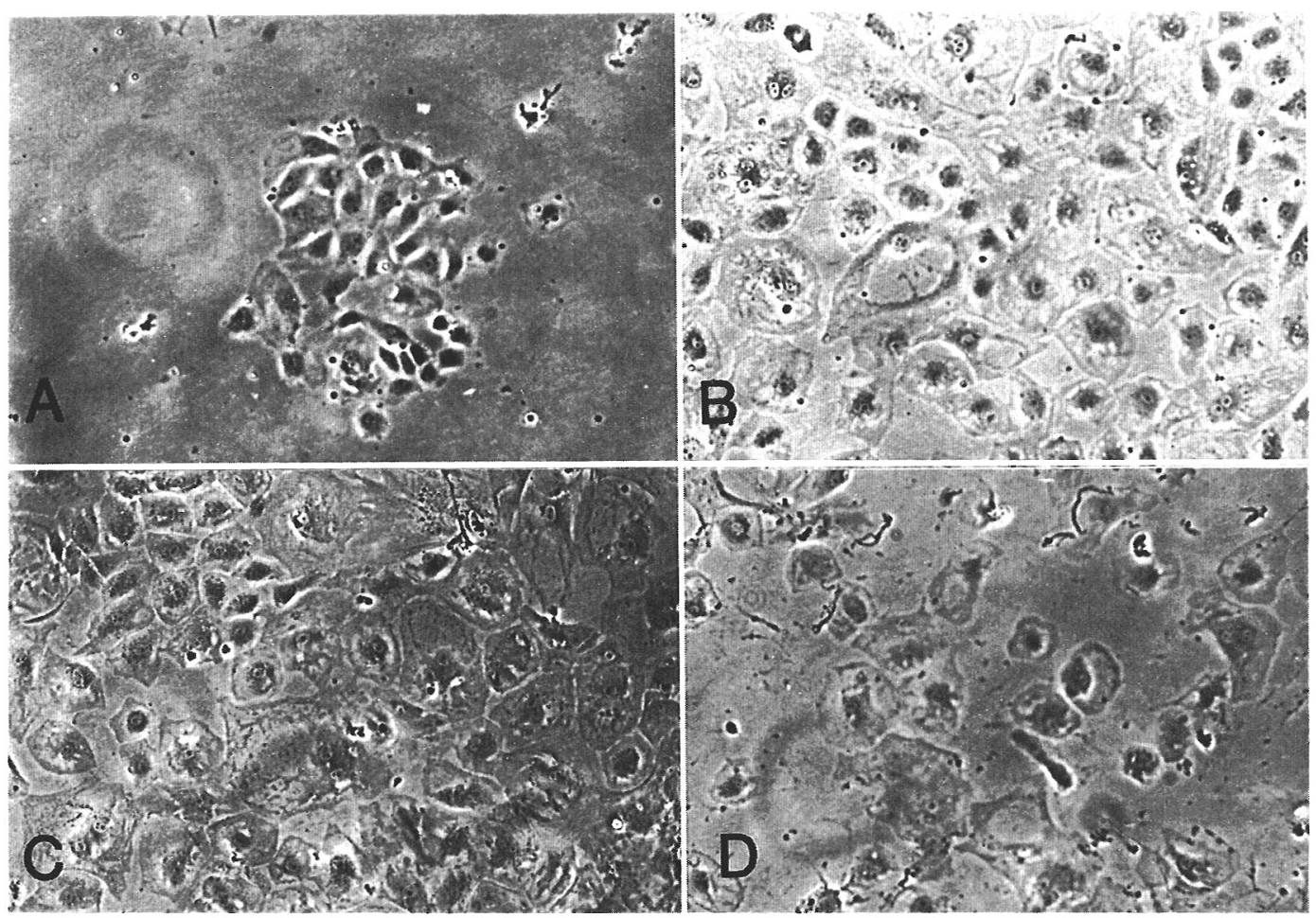

Fig. 4. Four frames in a time lapse cinemicrography series of an RLEC-2 primary culture. The frames were taken at $0 \mathrm{~h}(\mathrm{~A}), 931 / 3 \mathrm{~h}(\mathrm{~B}), 2131 / 3 \mathrm{~h}(\mathrm{C})$ and $5131 / 3 \mathrm{~h}$ (D) after the initiation of cinemicrography $(\times 50)$. Note the appearance of binucleated cells, the heterogeneity of cell morphology, the intercellular space present, and cell clustering during clonal development.

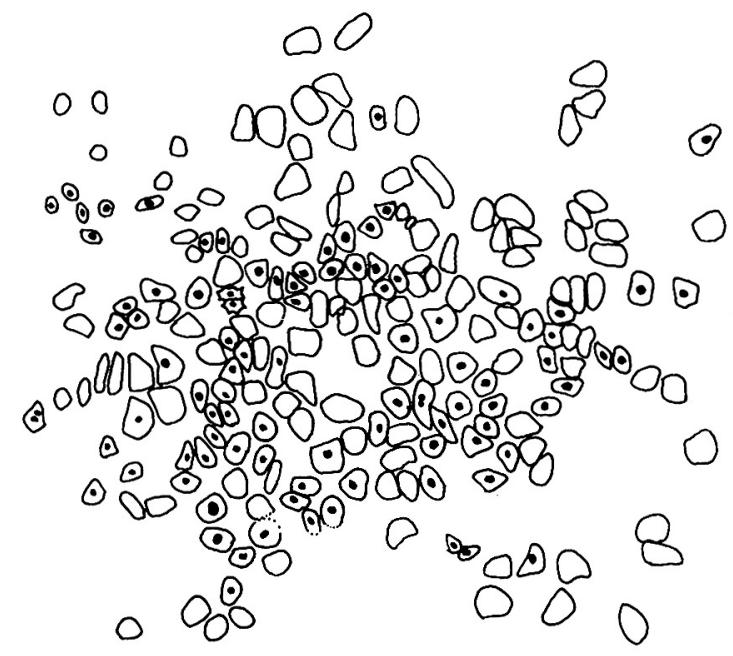

Fig. 5. Distribution of labelled nuclei in a colony that was nearly fully developed $(\times 60)$. 
$24 \mathrm{~h}$. In their autoradiograms the labelled nuclei were not distributed evenly in a colony; they tended to form clusters. These clusters, however, were scattered within the colony and showed no particular localization at the center, or along the periphery.

This clustering of DNA-synthesizing cells, without doubt, corresponds to the clustering of dividing cells within a colony (Fig. 4. Columns B and C). An example of an autoradiogram for a relatively small colony is shown in Fig. 5. The major cause of the location-dependent variations in the DNA synthesizing potential of a colony is considered to be due to the clustering of dividing cells all over the colony, not to the distance from the center of a colony.

In family tree mitosis, incomplete division and death also appeared (Column D of Fig. 1). Although very rare, multipolar divisions also were found (Fig. 3). The interphase period varied greatly. Incomplete division was frequently followed by a long interphase. Although not shown in these family trees, incomplete division also often was followed by binucleation. Evidently the limitation for proliferative potential was manifested in the family tree by the appearance of a long interphase, by an incomplete division seldom followed by division and by death.

\section{DISCUSSION}

For genealogical purposes, we have considered several other cell culture systems; mouse fibroblasts (17), human liver epithelial-like cells (16, Matsumura and Miyashita, unpublished), and HDFs (Matsumura and Nitta, unpublished) as candidate systems for cell family trees. The RLEC system is the most advantageous in several respects: Its proliferative life span is short enough to be covered in one cinemicrographic film series. Also, these cells stay in a single layer and move less than do fibroblasts. In addition, the polygonal shape of these epithelial-like cells makes film analysis easy. These advantages probably are shared by the epithelial-like cells of other rodents and small animals. To our knowledge, the RLEC system described here is the first such system to enable us to reconstitute the whole profile of finite proliferation from a single family tree.

Because HDF populations have been studied most among the finitely proliferative populations, we will discuss our data mainly in terms of the results and conclusions developed for HDFs. When a serial transfer of an HDF population is made and after it has almost lost its proliferative potential, a considerable number of the cell population become binucleated and continue on into $S$ phase (19). This phase we call Late Phase III (19). Family trees of our RLEC primary-culture clones manifested a phase which essentially is the same as the Late Phase III of the HDFs. We consider these family trees to relate Late phase III, (originally a concept of cell population) to the life phases of individual cells because, when a cell has once experienced incomplete division, it has little ability to return to the mitotic cycle, and after incomplete division a cell often becomes binucleate.

During the development and regeneration of liver tissue, cells that are no longer in the cell division cycle, and still become polyploid and multinucleated are present $(4,20,29)$. We previously suggested that cells similar to in vivo hepatocytes (in that they become polyploid and multinucleated, and can be said to be in a "cell spiral" rather than a "cell cycle") are present in vitro (16). The repeated incomplete divisions in our data are evidence of the presence of the cell spiral phenomenon in RLECs. Although not reported here, we noted that a fully developed clone of RLEC contained 
a considerable number of polyploid cells, which also is evidence of the cell spiral.

A large number of the clones in primary RLEC culture did not have an indefinite proliferative potential. But, when a large number of RLECs have been kept in primary culture, a cell line with indefinite proliferative potential frequently could be obtained $(5,7,8,23,27)$. Although the chances for success are small, we now are trying to record the process involved in producing indefinite proliferation by cinemicrography.

We conclude that the decrease in clonal RLEC populations in primary culture is not due to the post-confluence inhibition of proliferation nor to nutritional deprivation. It is due to the limited potential of cell proliferation (the Phase III phenomenon) as observed for serial transfers of HDF populations. Also, these family trees provide evidence for the presence of unidirectional changes in cell life, a cell spiral after the usual cell cycle.

Note added in proof. The possibility that RLECs are rather nonparenchymal than immature parenchymal liver epithelial cells has been suggested (Ichihara, A. et al., Mol. and Cell. Biochem. 43, 145-160, 1982). A rare family tree of RLECs Which we regard as covering a part of the process toward immortalization will be described in a forthcoming paper (Matsumura, T., Cell Biol. Intl. Reports, in press).

Acknowledgements. We are grateful to Professor Yoshitaka Nagai for his on-going encouragement during these experiments and to professer Masatoshi Sakka for discussion. We thank Mrs. Keiko Nitta and Mrs. Shigeyo Miyashita for their participation in the unpublished studies that preceeded this publication and Miss Noriko Munesawa, for her assistance in preparing the manuscript. This work was supported in part by grants from the Ministry of Education, Science and Culture of Japan and from the Institute of Physical and Chemical Research.

\section{REFERENCES}

1. Absher, P.M., R.G. Absher and W.D. Barnes. Genealogies of clones of diploid fibroblasts. Cinemicrophotographic observations of cell division patterns in relation ot population age. Exp. Cell Res. 88, 95-104, 1974

2. Absher, P.M. and R.G. AbSher. Clonal variation and aging of diploid fibroblasts. Cinematographic studies of cell pedigrees. Exp. Cell Res. 103, 247-255, 1976

3. Bell, E., L.F. Marek, D.S. Levinstone, C. Merrill, S. Sher, I.T. Young and M. Eden. Loss of division potential in vitro: Aging or differentiation? Science 202, 1158-1163, 1978

4. Brodsky, W. Ya. and I.V. Uryvaeva. Cell polyploidy: Its relation to tissue growth and function. Int. Rev. Cytol. 50, 275-332, 1977

5. Coon, H.G. Clonal culture of differentiated rat liver cells. J. Cell Biol. 39, 29a, 1968

6. Cristofalo, V.J. and B.B. Sharf. Cellular senescence and DNA synthesis. Thymidine incorporation as a measure of population age in human diploid cells. Exp. Cell Res. 76, 419-427, 1973

7. Gerschenson, L.E., M. Andersson, J. Molson and T. OKigaki. Tyrosine transaminase induction by dexamethasone in a new rat liver cell line. Science 170, 859-861, 1970

8. Grisham, J.W. Cell types in long term propagable cultures of rat liver. Annals of New York Academy of Sci. 349, 128-137, 1980

9. Grove, G.L. and V.J. Cristofalo. The transition probability model and the regulation of proliferation of human diploid cell cultures during aging. Cell Tissue Kinet. 9, 395-399, 1976

10. HAYfLICK, L. The cellular basis for biological aging. in Handbook of the Biology of Aging, ed. Finch, C.E. and L. Hayflick, Van Nostrand Reinhold Co., New York, pp. 159-186, 1977

11. Hayflick, L. and P.S. Moorhead. The serial cultivation of human diploid cell strains. Exp. Cell Res. 25, 585-621, 1961 
12. ICHIHARA, A. Relation of the characteristics of liver cells during culture, differentiation, and carcinogenesis. in Control Mechanisms in Cancer, ed. Criss, W.E., T. Ono and J.R. Sabine, Raven Press, New York, pp. 317-327, 1976

13. Katsuta, H. and T. Takaoka. Carcinogenesis in tissue culture. II: Proliferation-inducing effect of 4-dimethyl-aminoazobenzene on normal rat liver cells in culture. Japan. J. Exp. Med. 35, 209-230, 1965

14. Katsuta, H. and T. TAKAOKA. Improved synthetic media suitable for tissue culture of various mammalian cells. Methods in Cell Biol. 14, 145-158, 1976

15. MacPherson, I. The characteristics of animal cells transformed in vitro. in Advances in Cancer Research, Vol. 13, ed. G. Klein, and S. Weinhouse, Academic Press, New York, pp. 169-215, 1970

16. Matsumura, T. Multinucleation and polyploidization of aging human cells in culture. in Aging Phenomena, ed. Oota, K., T. Makinodan, M. Iriki and L.S. Baker, Plenum Press, New York, pp. 31-38, 1980

17. Matsumura ,T., S. Miyashita and T. Ohno. Conversion of proliferation and production of the colony stimulating factor during serial passage of mouse fibroblasts in culture. Cell Structure and Function 4, 267-274, 1979

18. Matsumura, T., T. Yamanaka, S. Hashizume, Y. Irie and K. Nitta. Tissue dispersion, cell harvest and fluid suspension culture by the use of bacterial neutral protease. Japan. J. Exp. Med. 45, 377-382, 1975

19. Matsumura, T., Z. Zerrudo and L. Hayflick. Senescent human diploid cells in culture: Survival, DNA synthesis and morphology. J. Gerontology 34, 328-334, 1979

20. Nadal, C., F. Zajdela. Polyploidie somatique dans le foie de rat. I. Le rôle des cellules binucléées dans la genèse des cellules polyploides. Exp. Cell Res. 42, 99-116, 1966

21. Sakka, M., H. Katsuta and T. TAKaOKa. Kinetics of microcolonies of cultured mammalian cells after gamma irradiation. Tohoku J. Exp. Med. 117, 299-309, 1975

22. SASAKI, H. and H. Yoshinaga. Study of proliferation kinetics of irradiated mammalian cells incorporating timelapse photography. in Fraction Size in Radiobiology and Radiotherapy, ed. Sugahara, T., L. Révész and O. Scott, Igaku Shoin Ltd., Tokyo, pp. 38-50, 1973

23. Schaeffer, W.I. The long term culture of a diploid rat hepatocyte cell strain. Annals New York Acad. Sci. 349, 165-182, 1980

24. SмIтн, J.A. Application of the theory of transition probability in "aging" WI38 cells: Similar behaviour of clonogenic cells from early and late passage cultures. Cell Biol. Intl. Reports 1, 283-289, 1977

25. Tномpson, L.H. and H.D. Suit. Proliferation kinetics of X-irradiated mouse L cells studied with time-lapse photography. II. Int. J. Radiat. Biol. 15, 347-362, 1969

26. Todaro, G.J. and H. Green. Quantitative studies of the growth of mouse embryo cells in culture and their development into established lines. J. Cell Biol. 17, 299-313, 1963

27. Tokiwa, T., H. Nakabayashi, M. Miyazaki and J. Sato. Isolation and characterization of diploid clones from adult and newborn rat liver cell lines. In vitro 15, 393-400, 1979

28. Van Zoelen, E.J.J., P.T. VAn Der SAag and S.W. De LaAT. Family tree analysis of a transformed cell line and the transition probability model for the cell cycle. Exp. Cell Res. 131, 395 406, 1981

29. Wheatley, D.N. Binucleation in mammalian liver. Studies on the control of cytokinesis in vivo. Exp. Cell Res. 74, 455-465, 1972

30. Yasukawa, M., T. Terasima, M. Yamada and T. Matsumura. Inactivation of proliferative capacity of cultured mammalian cells by liquid nitrogen storage procedure. Cryobiology 11, 493-499, 1974 